Aspirasi: Jurnal Masalah-Masalah Sosial | Volume 11, No. 1 Juni 2020

ISSN: 2086-6305 (print) ISSN: 2614-5863 (electronic)

doi: 10.22212/aspirasi.v11i1.1505

link online: http://jurnal.dpr.go.id/index.php/aspirasi/index

\title{
Pengelolaan Sampah di Kota Bertipe Sedang: Studi Kasus di Kota Cirebon dan Kota Surakarta
}

\author{
Waste Management in Medium Type City: \\ Case Study in Cirebon City and Surakarta City \\ Rohani Budi Prihatin \\ rohani.prihatin@dpr.go.id \\ Pusat Penelitian Badan Keahlian DPR RI \\ Jl. Gatot Subroto, Senayan, Jakarta
}

Naskah diterima: 17 Desember 2019 | Naskah direvisi: 3 Juni 2020 | Naskah diterbitkan: 30 Juni 2020

\begin{abstract}
The continuity of development and the rate of economic growth accompanied by an increase in the number of populations generally creates problems in urban areas, which of them is the generation of waste. Among the two cities that are experiencing growth and facing waste problems are Cirebon City and Surakarta City. Based on urban typology based on population, these two cities fall into the medium city category. The average type of city, in general, has relatively not experienced acute waste problems, especially when compared to large cities such as Bandung and Jakarta. This study focused on the preparation of these cities in anticipation of the emergence of garbage problems in the future when they head to and become a big city (population above 1 million). Using in-depth interviews with Environmental Office and garbage bank business actors in waste management in the two cities and the author's direct observation found the fact that waste management in both cities still applied the 3P pattern, i.e. pengumpulan (collection), pengangkutan (transportation), and pembuangan (disposal). This means that waste management is carried out by collecting as much as possible, then transported as quickly as possible and after that disposed of as far as possible. Even more worrying, the running of waste management in the landfill is still managed by an open dumping mechanism or the garbage is only stacked open without any significant management. Sooner or later, waste in these cities will grow faster than the management solution. One day, landfills in the two cities are no longer able to accommodate them.
\end{abstract}

Keywords: Cirebon; open dumping; waste management; Surakarta

Abstrak: Pembangunan dan laju pertumbuhan ekonomi yang disertai dengan peningkatan jumlah populasi umumnya menimbulkan masalah di daerah perkotaan, yang di antaranya adalah timbulnya sampah. Dua kota yang mengalami pertumbuhan dan menghadapi masalah persampahan adalah Kota Cirebon dan Kota Surakarta. Berdasarkan tipologi perkotaan dilihat dari sisi populasi, kedua kota ini masuk dalam kategori kota sedang. Kedua kota tersebut secara umum, relatif tidak mengalami masalah persampahan yang akut, terutama jika dibandingkan dengan kota-kota besar seperti Bandung dan Jakarta. Studi ini difokuskan pada persiapan kotakota ini untuk mengantisipasi munculnya masalah sampah di masa depan ketika mereka menuju dan menjadi kota besar (populasi di atas 1.000.000). Menggunakan wawancara mendalam dengan Dinas Lingkungan Hidup dan pelaku bisnis bank sampah di dua kota tersebut, dan melalui pengamatan langsung, penulis menemukan fakta bahwa pengelolaan sampah di kedua kota masih menerapkan pola 3P (pengumpulan, pengangkutan, dan pembuangan). Hal ini berarti bahwa pengelolaan sampah dilakukan dengan mengumpulkan sebanyak mungkin, kemudian diangkut secepat mungkin, dan setelah itu dibuang sejauh mungkin. Yang lebih mengkhawatirkan lagi, pengolahan sampah di TPA masih dilakukan dengan mekanisme open dumping atau sampah 
hanya ditumpuk terbuka tanpa ada pengelolaan khusus. Cepat atau lambat, sampah di kota-kota ini akan tumbuh lebih cepat daripada solusi pengelolaannya. Suatu hari nanti, tempat pembuangan sampah di kedua kota tidak lagi dapat menampung sampah yang ada.

Kata Kunci: Cirebon; pembuangan terbuka; pengelolaan sampah; Surakarta

\section{Pendahuluan}

Eksistensi sebuah kota akan selalu berhubungan erat dengan perkembangan lahan, baik dalam kota itu sendiri maupun pada daerah sekitarnya. Selain itu, lahan juga berhubungan erat dengan manusia dan lingkungan. Oleh karena itu, perkembangan dan pertumbuhan kota yang baik terjadi manakala sebuah kota dapat menyeimbangkan antara ketersediaan lahan dengan kepadatan penduduk yang akan ditampung dalam kota tersebut sehingga permasalahan lingkungan tidak terjadi. Banyaknya masalah yang muncul akibat pertumbuhan kota yang ce-pat biasanya terjadi karena tidak diimbangi dengan penyediaan prasarana, perencanaan yang kurang matang, dan terbatasnya kemampuan fiskal untuk membiayai pembangunan prasara-na tersebut.

Kontinuitas pembangunan dan laju pertumbuhan ekonomi yang disertai dengan pertambahan jumlah penduduk umumnya melahirkan permasalahan perkotaan. Perbaikan taraf hidup cenderung akan meningkatkan konsumsi masyarakat terhadap barang, dan ini merupakan cikal bakal dihasilkannya sampah. Menurut Letcher dan Valerro (2019: 3), suatu wilayah yang mengalami pertumbuhan ekonomi biasanya selalu diiku-ti oleh meningkatnya produksi sampah. Sayangnya, di saat bertambahnya produksi sampah, belum muncul kesadaran masyarakat untuk memperlakukan sampah dengan baik. Pada sisi lain, pertambahan volume sampah ini juga tidak diiringi dengan kesiapan pemerintah atau pemerintah daerah dalam menyiapkan infrastruktur pengelolaan sampah di wilayahnya.

Tingkat produksi sampah Indonesia per kapita mencapai 0,6 kg/orang/hari untuk wilayah perkotaan dan $0,3 \mathrm{~kg} / \mathrm{orang} / \mathrm{hari}$ untuk wilayah pedesaan di tahun 2005. Seiring dengan pertumbuhan ekonomi, produksi sampah per kapita akan terus naik sehingga di tahun 2030 mencapai $1,2 \mathrm{~kg} /$ orang/hari untuk perkotaan dan $0,55 \mathrm{~kg}$ /orang/hari untuk pedesaan (Bappenas, 2010). Bank Dunia menyebutkan, jumlah sampah padat yang diproduksi Indonesia secara nasional mencapai 151.921 ton per hari. Ini berarti setiap penduduk Indonesia rata-rata membuang sampah 0,85 kg per hari (Paramita, 2016: 27). Dari total sampah yang dihasilkan hanya 40,09\% yang dibuang ke Tempat Pembuangan Akhir (TPA), 35,49\% dibakar, $1,61 \%$ didaur ulang, 7,54\% ditimbun, dan 15,2\% dibuang ke jalan, sungai, dan lahan lainnya. Hanya sekitar 70\% sampah yang berhasil dikumpulkan, sementara sisanya terbuang mencemari lingkungan (Tim Riset dan Analis Katadata, 2019).

Peningkatan volume sampah di suatu wilayah tanpa diimbangi dengan peningkatan mutu pengelolaan sampah akan berpotensi menimbulkan berbagai dampak negatif bagi kehidupan manusia. Dari sisi kesehatan, sampah yang tidak terkelola dengan baik dapat menyebabkan penyebaran penyakit sehingga menurunkan kualitas kesehatan masyarakat. Dari segi lingkungan, sampah merupakan sumber pencemaran, baik itu pencemaran air, tanah, maupun udara. Sampah juga dapat menjadi penyebab banjir ketika sampah banyak dibuang ke badan air. Bahkan sampah juga berkontribusi terhadap peningkatan emisi gas rumah kaca (GRK) di atmosfer yang merupakan pemicu pemanasan global dengan melepaskan gas metan dan karbondioksida. Potensi gas metan dari sektor sampah di Indonesia sangat besar yakni sekitar 109,96 Gg per tahun di mana terdapat lebih kurang 400 TPA yang hampir semuanya beroperasi secara open dumping. Tingginya potensi gas metan ini disebabkan kondisi TPA umumnya 'basah' akibat iklim dan juga komposisi sampah organik yang hampir 60-70\% (Purwanta, 2009).

Dari segi sosial, sampah dapat menurunkan kerukunan antar-warga ketika ada masyarakat yang membuang sampah sembarangan dan mengotori lingkungan. Selain akan menimbulkan lingkungan yang bau, kotor, dan tidak nyaman bagi masyarakat. Dari segi ekonomi, sampah dapat memberikan dampak negatif terhadap sektor kepariwisataan (Qodriyatun, 2018). Sampah 
yang menumpuk dan tidak terkelola dengan baik akan mengurangi minat wisatawan untuk datang ke kota tersebut. Selain itu, dibutuhkan biaya tinggi untuk mengatasi dampak yang dimunculkannya.

Harus diakui, sampah masih terus menjadi masalah bagi sebagian besar perkotaan. Rendahnya kesadaran masyarakat akan pengelolaan sampah dari sumbernya membuat pengelolaan sampah belum maksimal. Keterbatasan lahan TPA, buruknya sistem pengumpulan dan pengangkutan sampah yang kurang higienis, serta belum terpisah antara sampah organik dan anorganik di masyarakat turut menjadi penyebab masalah sampah di perkotaan.

Pengelolaan sampah di banyak kota di Indonesia selama ini ternyata menggunakan paradigma 3P (pengumpulan, pengangkutan, dan pembuangan) dan sepenuhnya tergantung dari keberadaan dan kapasitas TPA. Pengelolaan sampah dengan model kumpul-angkut-buang, dan penanganan sampah yang selalu menggunakan pendekatan open dumping (sampah dikumpulkan ke Tempat Pembuangan Sementara (TPS) untuk kemudian ditumpuk hingga hancur sendiri di TPA), tidak memadai untuk menangani timbulan sampah yang volumenya terus bertambah seiring bertambahnya jumlah penduduk dan meningkatnya pola konsumsi masyarakat. Jika model pengelolaan sampah seperti ini terus dilakukan, maka dalam 5-10 tahun ke depan pengelolaan sampah di banyak kota di Indonesia akan mengalami persoalan dengan habisnya masa pakai TPA. Sementara itu, lokasi TPA pengganti semakin sulit dicari. Sulitnya mencari lokasi TPA pengganti disebabkan karena terbatasnya lahan dan meningkatnya penolakan masyarakat terhadap keberadaan TPA, khususnya yang terletak di sekitar atau dekat dengan pemukiman penduduk.

Problem pengelolaan sampah umumnya mudah dilihat pada kota-kota yang sudah masuk kategori kota-kota besar seperti Jakarta, Bandung, Surabaya, dan lain-lain. Sementara pada kotakota yang bertipe sedang, problem tersebut belum terlihat, namun potensi masalah sebenarnya sudah mulai muncul dan sudah dirasakan.

Berdasarkan pengalaman selama ini, ratarata kota baru menyadari pentingnya pengelolaan sampah yang modern justru pada saat mereka sudah menjadi kota besar (berpenduduk di atas 1.000.000). Kesadaran tersebut jelas sangat terlambat karena pada saat itu lahan yang luas untuk menyediakan lokasi pengelolaan sampah sudah tidak tersedia lagi di wilayah kota. Umumnya, lahan yang tersedia sudah jauh dari lokasi perkotaan dan untuk menuju ke sana dan mengangkut sampah dibutuhkan transportasi pengangkutan sampah yang lagi-lagi membutuhkan pendanaan yang besar.

Salah satu kesalahan tata kelola sebuah perkotaan adalah anggapan bahwa tata kelola persampahan hanya diperlukan oleh kota-kota yang berskala besar. Banyak sekali kota-kota bertipe sedang yang mengelola sampahnya hanya sekadarnya saja sehingga ketika kota mereka berubah menjadi kota besar barulah mereka sadar segalanya sudah terlambat. Seakan-akan problem pengelolaan sampah hanya cukup dengan menyediakan lahan untuk dijadikan TPA.

Pengelolaan sampah saat ini menjadi tantangan utama hampir semua kota di Indonesia karena pesatnya urbanisasi dan kenaikan populasi. Hal tersebut terjadi karena sistem pengumpulan yang tidak efektif, cakupan pengepulan yang tidak memadai, dan sistem pengolahan dan pembuangan yang tidak tepat. Kemampuan pengelola kota menangani sampahnya dalam 10 tahun terakhir cenderung menurun, antara lain karena era otonomi dan kemampuan pembiayaan yang rendah.

Berdasarkan Laporan Kementerian Lingkungan Hidup pada tahun 2001 diperkirakan pengelola sampah kota hanya mampu melayani sekitar 32\% penduduk kota, dari 384 kota di Indonesia (Damanhuri, 2007). Tingginya eskalasi urbanisasi, menjadikan pemerintah daerah dituntut untuk meningkatkan pelayanan yang maksimal dalam rangka pemenuhan kebutuhan masyarakat. Salah satu pelayanannya adalah peng-elolaan sampah.

Berdasarkan Peraturan Pemerintah Nomor 26 Tahun 2008 tentang Rencana Tata Ruang Wilayah Nasional, Pasal 16 menyebutkan klasifikasi kota berdasarkan jumlah penduduknya terbagi menjadi kota kecil (jumlah penduduk 20.000-100.000 jiwa), kota sedang (jumlah penduduk 100.000-500.000 jiwa), kota besar 
(jumlah penduduk 500.000-1.000.000 jiwa), metropolitan (jumlah penduduk 1.000.000 5.000.000 jiwa), dan megapolitan (jumlah penduduk lebih dari 5.000.000 jiwa). Dalam studi ini, Kota Cirebon dipilih karena ia masuk dalam kategori kota bertipe sedang karena ia berpenduduk 305.889 (data penduduk tahun 2014). Sementara itu, Kota Surakarta juga dipilih sebagai studi kasus ini, walau berdasarkan tipologi perkotaan harusnya ia masuk kategori kota besar karena berpenduduk sebanyak 545.653. Namun, jika dibuatkan pembulatan, maka jumlah tersebut lebih mendekati ke kategori 500.000 (pembulatan ke bawah) daripada ke 1.000.000 penduduk (pembulatan ke atas). Oleh karena itu, dalam penelitian ini, Kota Surakarta tetap dimasukkan dalam kategori kota sedang.

Selain itu, dengan kategori jumlah penduduk, penelitian ini juga berdasarkan pengamatan di mana rata-rata kota yang bertipe sedang umumnya relatif belum mengalami problem persampahan yang akut, terutama jika dibandingkan dengan kota besar seperti Kota Bandung dan Kota Jakarta misalnya. Oleh karena itu, kedua kota ini belum memiliki banyak persoalan persampahan. Fokus kajian pada kedua kota tersebut menitikberatkan pada persiapan kota-kota tersebut dalam mengantisipasi timbulnya permasalahan sampah di kemudian hari pada saat mereka menuju dan menjadi kota besar.

Secara umum, problem pengelolaan sampah di perkotaan antara lain: kurangnya kesadaran masyarakat, kurangnya SDM untuk melaksanakan kebijakan yang sudah ditetapkan, kurangnya lahan, kurangnya peran swasta, terbatasnya anggaran, dan kebijakan pengelolaan sampah yang masih terdapat beberapa hal yang tidak sesuai dengan Undang-Undang Nomor 18 Tahun 2008 tentang Pengelolaan Sampah (UU Pengelolaan Sampah) dan Peraturan Menteri Dalam Negeri Nomor 33 tahun 2010 tentang Pedoman Pengelolaan Sampah.

Permasalahan-permasalahan tersebut umumnya terjadi di kota-kota yang sudah terlanjur menjadi kota berkategori besar. Namun, pada kotakota yang berkategori sedang sebenarnya problem atau permasalahan sampah belum sepenuhnya menjadi masalah. Pada kota-kota bertipe sedang, peluang untuk membangun sistem pengelolaan sampah yang efektif dan efisien masih terbuka lebar. Penelitian ini mengasumsikan bahwa semakin besar sebuah kota maka akan semakin kompleks tata kelola sampahnya. Sebaliknya, semakin kecil sebuah kota akan semakin mudah untuk menyelesaikan permasalahan sampahnya.

Berdasarkan asumsi tersebut maka pertanyaan penelitian yang akan digali adalah: (1) Bagaimana pengelolaan sampah di kedua kota bertipe sedang tersebut? (2) Faktor apa saja yang menjadi penghambat dan yang memengaruhi tingkat keberhasilan pengelolaan sampah pada kedua kota tersebut? (3) Langkah perencanaan apa saja yang mereka lakukan dalam rangka mengantisipasi sehingga kedua kota tersebut ke depan tidak mengalami problem pengelolaan sampah?

Tujuan penelitian ini adalah mengetahui pelaksanaan serta mengetahui faktor-faktor yang memengaruhi pengelolaan sampah di kotakota yang bertipe sedang seperti yang terjadi di Kota Cirebon dan Kota Surakarta. Juga untuk mengetahui langkah antisipasi apa yang diperlukan oleh kedua kota tersebut ke depan. Kegunaan dari penelitian ini, secara akademis dapat memberikan sumbangan pemikiran terhadap kebijakan tentang pengelolaan sampah yang seharusnya dilakukan oleh pemerintah kota (pemkot) yang berkategori sedang dalam mempersiapkan menuju menjadi kota besar. Secara praktis, penelitian ini dapat memberikan sumbangan pemikiran terkait pelaksanaan fungsi pengawasan DPR terhadap pelaksanaan UU Pengelolaan Sampah.

Penelitian menggunakan pendekatan kualitatif. Metode ini dipilih untuk mendapatkan data dan informasi terkait pengelolaan sampah di kota-kota yang dijadikan sampel penelitian. Teknik pengumpulan data dilakukan melalui wawancara dengan para stakeholders terkait dan pertanyaan bersifat terbuka sehingga memberi peluang bagi informan untuk memberikan data dan/atau informasi yang sebanyak-banyaknya kepada peneliti.

Proses pengumpulan data dalam penelitian ini adalah dengan menggunakan metode observasi, wawancara, dan dokumentasi. Teknik analisis data dalam penelitian ini adalah dengan pengumpulan data, reduksi data, penyajian 
data, dan verifikasi. Subjek penelitian ini adalah stakeholders yang terlibat dalam pengelolaan sampah di kota-kota tersebut (Dinas Persampahan/Lingkungan Hidup, dan warga masyarakat yang terlibat dalam pengelolaan sampah), sementara obyek penelitian ini adalah tata kelola persampahan. Lokasi penelitian studi ini adalah Kota Cirebon dan Kota Surakarta. Penelitian di Cirebon dilakukan pada tanggal 1-8 Juni 2018, sedangkan penelitian di Surakarta dilakukan pada tanggal 14-21 Oktober 2018.

\section{Pengelolaan Sampah Perkotaan}

Seiring dengan bertambahnya jumlah penduduk suatu wilayah maka bertambah pula volume sampah yang dihasilkannya, dan menjadi masalah ketika sampah tersebut tidak terkelola dengan baik dan benar. Pengelolaan sampah dengan baik dan benar pada kenyataannya tidak hanya dikelola dari aspek teknisnya saja, tetapi juga aspek nonteknis.

Sejauh ini, paradigma pengelolaan sampah yang dilakukan di kota di Indonesia masih berpegang pada prinsip 3P (pengumpulan, pengangkutan, dan pembuangan). Maksudnya, sampah dikumpulkan sebanyak-banyaknya, kemudian diangkut secepat-cepatnya dan dibuang sejauh-jauhnya. Sampah masih dianggap sebagai sisa hasil kegiatan manusia yang tidak memiliki nilai dan harus segera dijauhkan atau dibuang serta jika perlu dimusnahkan (Kuncoro, 2009).

Pengelolaan sampah dengan menggunakan paradigma $3 \mathrm{P}$ memiliki ketergantungan yang tinggi terhadap keberadaan TPA (Wibowo, 2009) karena dalam pengelolaan sampah dengan model 3P tidak ada proses pengurangan timbulan sampah mulai dari sumbernya. Akibatnya dibutuhkan sarana angkut sampah yang banyak dan lahan TPA yang luas. Tidak hanya itu, penanganan sampah di TPA menjadi lebih berat dan dibutuhkan biaya yang besar untuk menanganinya. TPA dengan sistem lahan urug saniter yang ramah lingkungan terbukti tidak ramah dalam aspek pembiayaan, karena membutuhkan biaya tinggi untuk investasi, konstruksi, operasi, dan pemeliharaannya.

Pada awal Mei 2008, Pemerintahan Indonesia mengesahkan UU Pengelolaan Sampah sebagai payung hukum nasional bagi penyelenggaraan pengelolaan sampah. UU tersebut memerintahkan pemerintah daerah untuk menutup semua TPA yang dioperasikan sebagai pembuangan sampah terbuka (open dumping) dalam jangka waktu maksimal 5 tahun atau sampai 2013. Dalam rentang waktu yang sama, TPA baru akan dibangun untuk menggantikannya. Pembangunan tempat pembuangan sampah baru harus memakai sistem sanitary landfill sesuai dengan standar dan peraturan yang berlaku. Namun, penelitian yang dilakukan oleh Meidiana dan Gamse (2011) mengidentifikasi bahwa sebagian besar TPA dioperasikan sebagai TPA open dumping terkontrol, sekalipun tempat pembuangan sampah tersebut rata-rata awalnya didesain sebagai sanitary landfill (Munawar \& Fellner, 2014). Sebagai konsekuensinya praktik ini antara lain menimbulkan emisi lindi yang mengandung polutan organik dan kandungan nitrogen serta gas rumah kaca (greenhouse gases atau GHG).

Menurut UU Pengelolaan Sampah pada Pasal 1 ayat (5), disebutkan bahwa pengelolaan sampah adalah kegiatan yang sistematis, menyeluruh, dan berkesinambungan, yang meliputi pengurangan dan penanganan sampah. Paradigma pengelolaan sampah berdasarkan UU Pengelolaan Sampah tidak lagi bertumpu pada pendekatan akhir seperti yang dilakukan selama ini. UU Pengelolaan Sampah memandang sampah sebagai sumber daya yang memiliki nilai ekonomi sehingga pengelolaannya dilakukan mulai dari hulu. Oleh karenanya, pengurangan sampah dari sumber menjadi hal utama dalam pengelolaan sampah. Sebagaimana disebutkan dalam Pasal 20 UU Pengelolaan Sampah, kegiatan pengurangan sampah dilakukan melalui kegiatan pembatasan timbulan sampah, pendauran ulang sampah, dan pemanfaatan kembali sampah. Ketiga kegiatan tersebut merupakan perwujudan dari prinsip pengelolaan sampah yang berwawasan lingkungan yang disebut 3R (reduce, reuse, recycle).

Selanjutnya dalam Pasal 22 diuraikan lima aktivitas utama dalam kegiatan penanganan sampah yang meliputi pemilahan, pengumpulan, pengangkutan, pengolahan, dan pemrosesan akhir sampah. Pemilahan dilakukan dalam bentuk pengelompokan dan pemisahan sampah sesuai dengan jenis, jumlah, dan/atau sifat sampah. 
Pengumpulan dalam bentuk pengambilan dan pemindahan sampah dari sumber sampah ke TPS atau tempat pengelolaan sampah 3R skala kawasan (TPS 3R), atau tempat pengelolaan sampah terpadu (TPST). Pengangkutan dalam bentuk membawa sampah dari sumber dan/atau dari tempat penampungan sampah sementara ke TPA atau TPST. Pengolahan dalam bentuk mengubah karakteristik, komposisi dan jumlah sampah, dan pemrosesan akhir sampah dalam bentuk pengembalian sampah dan/atau residu hasil pengolahan sebelumnya ke media lingkungan secara aman.

Pengelolaan sampah mulai dari hulu, dengan mengurangi timbulan sampah dari sumber, merupakan paradigma baru yang diperkenalkan UU Pengelolaan Sampah. Secara garis besar, kegiatan di dalam pengelolaan sampah meliputi pengendalian timbulan sampah, pengumpulan sampah, transfer dan transport, pengolahan dan pembuangan akhir. Titik awal munculnya permasalahan dalam pengelolaan sampah sebenarnya berawal dari rumah tangga. Masyarakat seharusnya memahami bahwa sampah merupakan masalah bersama akan lebih mudah untuk menerapkan pemilahan sampah sedari awal. Peran serta masyarakat dalam pengelolaan sampah memang sangat penting karena konsep penanganan sampah yang baik adalah penanganan sampah yang dimulai dari sumbernya. Produsen sampah utama adalah masyarakat sehingga masyarakat itu sendiri yang harus bertanggung jawab terhadap sampah yang mereka produksi (polluters must pay). Semakin dekat dengan sumbernya maka semakin besar rasa memiliki (sense of belonging) dan rasa tanggung jawab orang untuk mengelola sampahnya.

Cara kerja paradigma lama dengan paradigma baru dalam pengelolaan sampah dapat dilihat pada Gambar 1. Paradigma lama digambarkan seperti sebuah piramida yang menunjukkan kegiatan yang paling banyak harus dilakukan adalah di pembuangan akhir. Inilah paradigma 3P (pengumpulan, pengangkutan, dan pembuangan). Sebagai konsekuensinya dibutuhkan biaya investasi dan operasional yang tinggi, termasuk untuk mengatasi dampak lingkungan yang ditimbulkan. Penerapan pengelolaan sampah kota yang menekankan semua bentuk buangan padat merupakan residu yang harus dibuang ke tempat pemrosesan akhir tidak mendukung bagi pembangunan yang berkelanjutan. Karena paradigma dalam pengelolaan sampah yang lebih menekankan pada penanganan sampah di akhir banyak menimbulkan masalah, kemudian muncul paradigma baru dalam pengelolaan sampah, yaitu paradigma 4P (pemilahan, pengolahan, pemanfaatan, dan pembuangan residu). Paradigma baru ini lebih menekankan pada proses pengurangan sampah pada sumbernya sehingga sampah yang dibuang ke TPA seminimal mungkin. Model pengelolaan sampah semacam ini akan mengurangi biaya investasi dan operasional yang diperlukan dan juga mengurangi dampak lingkungan.

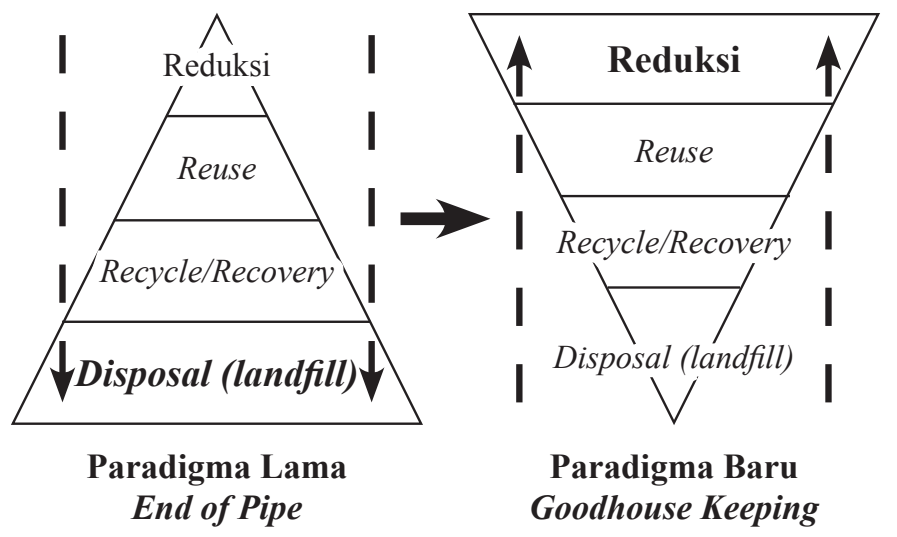

Gambar 1. Perbedaan Paradigma Lama dan Paradigma Baru Pengelolaan Sampah Sumber: Diadaptasi dari Emillia, 2019 
Berdasarkan UU Pengelolaan Sampah, pemerintah dan pemerintah daerah merupakan pihak yang berwenang dan bertanggung jawab di bidang pengelolaan sampah, meskipun secara operasional pengelolaannya dapat bermitra dengan badan usaha. Organisasai persampahan dan kelompok masyarakat juga dapat dilibatkan dalam pengelolaan sampah. Dalam UU tersebut juga dinyatakan dengan tegas apa saja tugas dan kewenangan pemerintah dan pemerintah daerah dalam penyelenggaraan pengelolaan sampah sebagaimana disebutkan dalam Pasal 6 UU Pengelolaan Sampah. Tugas dan kewenangan tersebut adalah:

1) Menumbuhkembangkan dan meningkatkan kesadaran masyarakat dalam pengelolaan sampah;

2) Melakukan penelitian, pengembangan teknologi pengurangan, dan penanganan sampah;

3) Memfasilitasi, mengembangkan, dan melaksanakan upaya pengurangan, penanganan, dan pemanfaatan sampah;

4) Melaksanakan pengelolaan sampah dan memfasilitasi penyediaan prasarana dan sarana pengelolaan sampah;

5) Mendorong dan memfasilitasi pengembangan manfaat hasil pengolahan sampah;

6) Memfasilitasi penerapan teknologi spesifik lokal yang berkembang pada masyarakat setempat untuk mengurangi dan menangani sampah; dan

7) Melakukan koordinasi antarlembaga pemerintah, masyarakat, dan dunia usaha agar terdapat keterpaduan dalam pengelolaan sampah.

\section{Pengelolaan Sampah di Kota Cirebon}

Kota Cirebon mempunyai wilayah seluas $37,36 \mathrm{~km}^{2}$ (Badan Pusat Statistik Kota Cirebon, 2016) dengan produksi sampah hariannya mencapai $600 \mathrm{~m}^{3}$ per hari pada hari biasa (Radar Cirebon, 2018). Angka tersebut akan bertambah pada saat libur akhir pekan atau bertepatan dengan hari libur nasional. Semua sampah di Kota Cirebon akan berakhir di TPA Kopiluhur dengan luas 14 ha yang terletak di Kelurahan Argasunya, Kecamatan Harjamukti (Redaksi Aktual, 2016). Kota Cirebon sendiri terdiri dari 5 kecamatan dan
22 kelurahan dengan jumlah penduduk 328.239 jiwa.

Kota Cirebon merupakan kota perdagangan dan jasa, kalau dilihat dari sisi ekonominya. Sebagaimana kota-kota lain pada umumnya, Kota Cirebon juga punya masalah dalam pengelolaan sampah. Beberapa waktu lalu diberitakan bahwa sampah di beberapa TPS belum diangkut sehingga menumpuk dan tumpah ke badan jalan di beberapa penjuru Kota Cirebon. Banyak pengendara yang mengeluhkan bau sampah yang tidak sedap sehingga membuat mereka harus menutup hidung. Kejadian seperti ini tampaknya akan terus terjadi jika pola pengelolaan sampah tidak dilakukan dengan baik dan benar.

Harus diakui, perkembangan dan pertumbuhan Kota Cirebon memicu bertambahnya jumlah penduduk dan perkembangan sektor industri serta pembangunan fasilitas infrastruktur kota. Dampak dari perkembangan adalah semakin besarnya jumlah produksi sampah yang dihasilkan dan daya dukung lingkungan hidup yang semakin berkurang terhadap sampah tersebut. Volume sampah di Kota Cirebon antara tahun 2012 hingga tahun 2015 mengalami peningkatan tiap tahunnya. Namun, peningkatan volume sampah per hari ini tidak diiringi atau sebanding dengan peningkatan kapasitas TPA Kopiluhur Kota Cirebon. Saat ini, TPA Kopiluhur kapasitasnya sudah maksimal sehingga dalam waktu empat tahun ke depan harus dicarikan lokasi TPA yang baru sebagai penggantinya.

Secara umum, pengolahan sampah di Kota Cirebon khususnya di TPA Kopiluhur masih menggunakan sistem open dumping, di mana sampah yang datang ke lokasi TPA dibuang begitu saja dengan hanya sesekali ditutup dengan lapisan tanah. Namun, tidak serutin seperti pada model sistem controlled landfill yang tiap seminggu sekali ditutup dengan lapisan tanah dan juga tidak seideal sistem sanitary landfill di mana sampah dalam setiap harinya ditutup dan dilapisi dengan tanah.

Guna menghindari sampah bertumpuk di TPS, Pemkot Cirebon sebenarnya sudah mengupayakan berbagai solusi. Dalam wawancara dengan Kepala Dinas Lingkungan Hidup (DLH) Kota Cirebon, Abdullah Syukur (2018) menyatakan bahwa Pemkot Cirebon tengah 
merencanakan membuat TPS mobile untuk mengatasi masalah sampah di Kota Cirebon. TPS mobile ini dikhususkan untuk mengangkut sampah rumah tangga bagi warga yang rumahnya dalam radius $3 \mathrm{~km}$ untuk diperbolehkan membuang sampah pada TPS mobile tersebut. Nantinya truk beroperasi tiap pagi di pemukiman warga. Menurut Kepala DLH, cara ini dianggap lebih efektif dibanding warga diminta membuang langsung ke TPS. TPS mobile rencananya mulai beroperasi Oktober 2018, jika rencana ini berhasil maka Pemkot akan membongkar sejumlah TPS di Kota Cirebon yang berada di tempat strategis dan pusat keramaian warga (Kepala Dinas Lingkungan Hidup Kota Cirebon, 2018).

Permasalahan lain yang dihadapi Pemkot Cirebon adalah ditemukan sampah yang bukan berasal dari rumah tangga yang dibuang pada beberapa TPS. Padahal, berdasarkan Perda Pengelolaan Sampah, keberadaan TPS hanya diperuntukkan bagi sampah rumah tangga. Bagi pengelola restoran, perusahaan, atau pelaku usaha diwajibkan untuk membuang secara langsung sampah produksinya ke TPA Kopiluhur. Banyaknya jenis sampah selain sampah rumah tangga yang ditemukan pada beberapa TPS semakin memperkuat indikasi adanya perusahaan atau pelaku usaha yang tidak membuang sampah produksinya ke TPA.

Kondisi tersebut diperparah dengan adanya sistem retribusi pelayanan persampahan yang membuat masyarakat menjadi semakin bergantung kepada pemerintah dan merasa tidak perlu ikut serta dalam pengelolaan sampah karena semua kegiatan pengelolaan sampah sudah mereka serahkan kepada pemerintah. Ditambah kurangnya sosialisasi dan rendahnya motivasi serta belum tertanamnya nilai-nilai lingkungan yang bersih dan sehat secara kuat di benak masyarakat dalam mengimplementasikannya, membuat masyarakat kurang menghargai untuk menjaga lingkungan, termasuk untuk tidak membuang sampah sembarangan. Padahal keterlibatan masyarakat dalam pengelolaan sampah merupakan modal penting mengingat volume sampah yang selalu meningkat setiap harinya, sementara pada saat yang sama Pemkot tidak memiliki cukup dana untuk menggunakan teknologi canggih dalam pengelolaan sampah.
Produksi sampah Kota Cirebon diakibatkan dari adanya kegiatan industri, perdagangan, taraf hidup dan gaya hidup masyarakat, rumah tangga, dan sebagainya sehingga produksi sampah di kota Cirebon pada setiap harinya mencapai 600 $\mathrm{m}^{3}$. Sampah yang dapat terangkut sebanyak $550 \mathrm{~m}^{3} /$ hari (Radar Cirebon, 2018) dan sisanya dibakar, ditimbun sendiri dengan cara membuat lubang atau menggali tanah, dibuang secara sembarangan di tempat-tempat tertentu secara liar, dan lain sebagainya (illegal dumping).

Dalam rangka menciptakan strategi optimalisasi pengelolaan sampah, Dinas Lingkungan Hidup Kota Cirebon menjadikan peningkatan pemahaman serta partisipasi masyarakat dalam pengelolaan persampahan fokus prioritas dalam kegiatannya. Banyak faktor yang memengaruhi rendahnya tingkat pemahaman dan partisipasi masyarakat. Salah satunya adalah aktivitas masyarakat tiap harinya yang sibuk dengan urusan masing-masing sehingga menjadi kurang memperhatikan pengelolaan sampah. Padahal, dalam pengelolaan sampah dibutuhkan dukungan dan peran serta masyarakat yang secara tidak disadari telah terlibat dalam kegiatan persampahan sedari awal. Selain meningkatkan partisipasi masyarakat dalam pengelolaan sampah, Dinas Lingkungan Hidup Kota Cirebon juga berupaya agar masyarakat dapat meminimalisir produksi sampah dan mengurangi sampah yang dibuang ke TPS dan TPA.

Dari segi payung hukum, Kota Cirebon telah memiliki Peraturan Daerah Nomor 4 Tahun 2018 tentang Pengelolaan Sampah. Sebelum adanya Perda ini, Pemkot Cirebon menggunakan Perda Pengelolaan Kebersihan yang dalam penerapannya dirasa lebih sulit karena bersifat umum. Perda yang baru tersebut selain mengatur hak dan kewajiban masyarakat sebagai penghasil sampah termasuk aturan dan sanksi bagi siapapun yang melanggar, dengan sengaja membuang sampah sembarangan. Selain itu, Perda tersebut juga mengatur rencana induk dan studi kelayakan pengelolaan sampah rumah tangga dan sampah sejenis sampah rumah tangga. yang ditetapkan paling sedikit 10 tahun. Rencana induk tersebut paling tidak memuat pembatasan timbulan sampah, pendauran ulang dan pemanfaatan sampah, pengelolaan sampah dari sumber sampai pemrosesan akhir, dan juga pendanaan. 
Permasalahan pengelolaan sampah tidak akan pernah dapat diselesaikan jika hanya bertumpu pada pemerintah saja tanpa ada keterlibatan dari masyarakat sebagai sumber penghasil sampah itu sendiri. Kehadiran bank sampah yang dikelola oleh warga masyarakat adalah salah satu di antara upaya untuk melibatkan masyarakat dalam mengurangi timbulan sampah. Di antara bank sampah yang programnya berjalan di Kota Cirebon adalah Bank Sampah Mekar Berseri yang dipimpin oleh Bapak Pepep dan Ibu Nining Widaningsih yang beranggotakan 198 peserta, yang 50 di antaranya merupakan anggota koperasi bank sampah tersebut.

Menurut narasumber, Pepep (2018), tantangan awal yang dihadapinya saat memulai program bank sampah ini adalah kebiasaan buruk warga masyarakatnya yang membuang sampah ke laut dan pinggir sungai. Warga di wilayah pesisir seperti di Kelurahan Kasepuhan ini memang terbiasa membuang sampah ke laut untuk membuat tanah timbul akibat tumpukan sampah yang mengendap dan menjadi lahan yang dapat dijadikan lokasi mendirikan rumah. Pak Pepep menempuh berbagai cara untuk meyakinkan warga betapa kebersihan lingkungan itu penting. Meskipun hingga kini masih banyak warga yang belum mau mengubah kebiasaan membuang sampah ke laut, tapi tidak sedikit juga warga yang sadar akan kebersihan lingkungannya. Kelompok Pak Pepep baru bisa mengolah 5-6 kuintal sampah plastik yang diolah menjadi kerajinan. Selebihnya ia jual kepada pelapak dengan harga yang disepakati. Dari data ini membuktikan bahwa implementasi metode 3R di Kota Cirebon, belum banyak mengurangi timbulan sampah pada level komunitas (Pepep, 2018).

Contoh lain pengelolaan sampah dengan bank sampah di Kota Cirebon dilakukan oleh Rumah Zakat di Kelurahan Kesepuhan. Penelitian Soleman, Jaenudin, dan Erawan (2017) menunjukkan bahwa pelaksanaan program Bank Sampah di Rumah Zakat tersebut masuk dikategorikan baik oleh $67 \%$ responden dan dikategorikan kurang baik oleh 33\% responden. Pelaksanaan peran serta masyarakat dalam membuang sampah di daerah tersebut masuk dalam kategori baik dinilai oleh $70,5 \%$ responden, dan dikategorikan kurang oleh 29,5\% responden.
Penelitian tersebut juga menunjukkan adanya hubungan antara program Bank Sampah Rumah Zakat dengan peran serta masyarakat dalam membuang sampah di Kelurahan Kesepuhan Kota Cirebon tahun 2017.

Meskipun program bank sampah sejauh ini belum dapat berperan sebagai solusi atas permasalahan sampah, akan tetapi ada satu harapan yang sesungguhnya sangat penting dalam rangka pengelolaan sampah pada level masyarakat, yaitu terjadinya perubahan pola fikir pada individu-individu dalam masyarakat mengenai sampah. Muncul sikap masyarakat yang peduli terhadap kesehatan lingkungan, dan lebih dari itu, kesadaran ini diharapkan tidak hanya ada pada tataran individu melainkan mengkristal pada munculnya entitas masyarakat, atau gerakan-gerakan masyarakat yang bergerak untuk tujuan terciptanya lingkungan yang sehat melalui pengelolaan sampah yang baik dan benar.

Dari sisi kapasitas, TPA Kopi Luhur sebenarnya sudah mendekati penuh. Oleh karena itu, Pemkot Cirebon harus secepatnya mengantisipasi hal tersebut dengan membuat berbagai perencanaan. Berdasarkan studi terbaru yang dilakukan Isni, Sungkowo, dan Widiarti (2019), indeks risiko lingkungan TPA Kopi Luhur menghasilkan nilai 573,3536 yakni tergolong kategori bahaya sedang sehingga rekomendasi yang disarankan dalam penelitian tersebut adalah dapat meneruskan penggunaan TPA Kopi Luhur dengan catatan harus merehabilitasi menjadi lahan urug terkendali secara bertahap. Penambahan lahan urug dan perancangan lahan urug baru juga harus menggunakan sistem controlled landfill, sesuai dengan Peraturan Menteri Pekerjaan Umum Nomor 3 Tahun 2013. Selain itu, lahan urug baru tersebut juga harus dilengkapi dengan fasilitas perlindungan lingkungan seperti lapisan dasar, sistem drainase, jaringan pengumpul lindi, dan sistem pengendali gas. Dengan menerapkan sistem ini, maka TPA Kopi Luhur diperkirakan akan mempunyai umur pakai 6,6 tahun ke depan.

Tampaknya, revitalisasi TPA Kopi Luhur dengan mekanisme controlled landfill juga menemui kendala karena berdasarkan data dari Dinas Kebersihan dan Pertamanan Kota Cirebon, alokasi anggaran APBD pada tahun 2016 adalah Rp16.183.652.013 atau sebesar 1\% dari 
total APBD Kota Cirebon. Sementara itu, dari sisi penerimaan retribusi pengelolaan sampah tahun 2016 Dinas Kebersihan dan Pertamanan Kota Cirebon memperoleh pendapatan sebesar Rp2.091.000.000 (Pemerintah Kota Cirebon, 2017: 123).

Selain revitalisasi TPA Kopi Luhur, sebaiknya Pemkot Cirebon segera merealisasikan inisiatif mengenai pendirian TPA Regional. Sejauh ini memang ada usulan agar Kota Cirebon, Kabupaten Cirebon, dan Kabupaten Indramayu membangun Tempat Pengolahan dan Pemrosesan Akhir Sampah (TPPAS) Regional. Rencananya TPPAS Regional akan dibangun di Kecamatan Ciwaringin, Kabupaten Cirebon dengan lahan seluas 40 ha. Keberadaan TPPAS Regional ini memang sudah sangat mendesak karena TPA Kopi Luhur (Kota Cirebon) dan TPA Pecuk (Kabupaten Indramayu) sudah melebihi kapasitas. Lebih parah lagi, Kabupaten Cirebon sampai saat ini bahkan belum memiliki TPA.

Selain revitalisasi TPA dan rencana pembangunan TPPAS Regional, maka upaya yang perlu dilakukan Pemkot Cirebon adalah mendorong partisipasi masyarakat melalui penerapan pengelolaan sampah berbasis komunitas. Harus diakui, permasalahan pengelolaan sampah di Kota Cirebon tidak akan pernah dapat diselesaikan jika hanya bertumpu pada pemerintah saja tanpa ada keterlibatan dari masyarakat sebagai sumber penghasil sampah itu sendiri. Oleh karena itu, pilihan terbaik bagi Pemkot Cirebon adalah mengedukasi masyarakat tanpa lelah mengenai pentingnya keberadaan bank sampah sehingga potensi timbulan sampah dapat dikurangi. Hal ini akan meringankan beban TPA pada akhirnya.

\section{Pengelolaan Sampah di Kota Surakarta}

Selain Kota Cirebon, Kota Surakarta juga memiliki permasalahan pengelolaan sampah yang kurang lebih mirip. Kota Surakarta mempunyai luas wilayah seluas $44,04 \mathrm{~km}^{2}$ dengan produksi sampah hariannya mencapai 270 ton per hari pada hari biasa dan mencapai 293 ton ketika pada musim liburan (Mukti, 2018). Kesemua sampah tersebut berakhir di TPA Putri Cempo dengan luas 17 ha yang terletak di Kelurahan Mojosongo, Kecamatan Jebres, Surakarta (Triyono \& Patola, 2015).

Data di atas setidaknya membuktikan bahwa Kota Surakarta merupakan salah satu kota di Jawa Tengah yang perkembangannya pesat. Indikasi berkembangnya suatu kota biasanya ditandai dengan semakin tingginya jumlah penduduk dan bertambahnya aktivitas. Tidak dipungkiri lagi hal tersebut memicu semakin tingginya produksi sampah yang dihasilkan oleh kota tersebut setiap harinya. Satu orang penduduk di Kota Surakarta rata-rata membuang sampah sebesar $0,5 \mathrm{~kg}$ sampah/hari. Dengan jumlah penduduk 550.000 jiwa, rata-rata jumlah sampah kota yang dihasilkan dan dibuang ke TPA sebanyak 290 ton/hari (Kepala Seksi Pengelolaan Sampah Dinas Lingkungan Hidup Kota Surakarta, 2018). Berdasarkan data cakupan pelayanan, pada tahun 2013 jumlah penduduk Kota Surakarta yang mendapat layanan persampahan mencapai $86 \%$ dan diperkirakan akan meningkat menjadi 92\% pada tahun 2022.

Untuk kontinuitas pelayanan persampahan diperlukan fasilitas seperti kontainer sampah. Pada tahun 2013 terdapat 131 unit kontainer dan harus melakukan program $3 \mathrm{R}$ sebanyak 150,84 sampah $/ \mathrm{m}^{3} /$ hari sehingga pada tahun 2022 sampah 3R sebesar $581,71 \mathrm{~m}^{3} /$ hari. Berdasarkan pemetaan untuk layanan persampahan, masyarakat dapat mengetahui kondisi persampahan yang ada dan diharapkan dapat menangani masalah persampahan yang ada di Kota Surakarta. Target ini tentu akan sulit dicapai jika membebankan persoalan sampah kepada Pemkot Surakarta sepenuhnya.

Secara umum, operasionalisasi pengangkutan sampah di Kota Surakarta dibedakan berdasarkan sumber sampah. Sampah yang berasal dari pemukiman yang telah terkumpul di bak TPS kemudian diangkut dengan mobil bak sampah untuk selanjutnya dibuang ke TPA Putri Cempo. Sementara itu, sampah komersial pertokoan dikumpulkan dan dibuang di wadah sampah yang ada di depan toko masing-masing, kemudian diangkut ke TPA (lihat Bagan 2). 


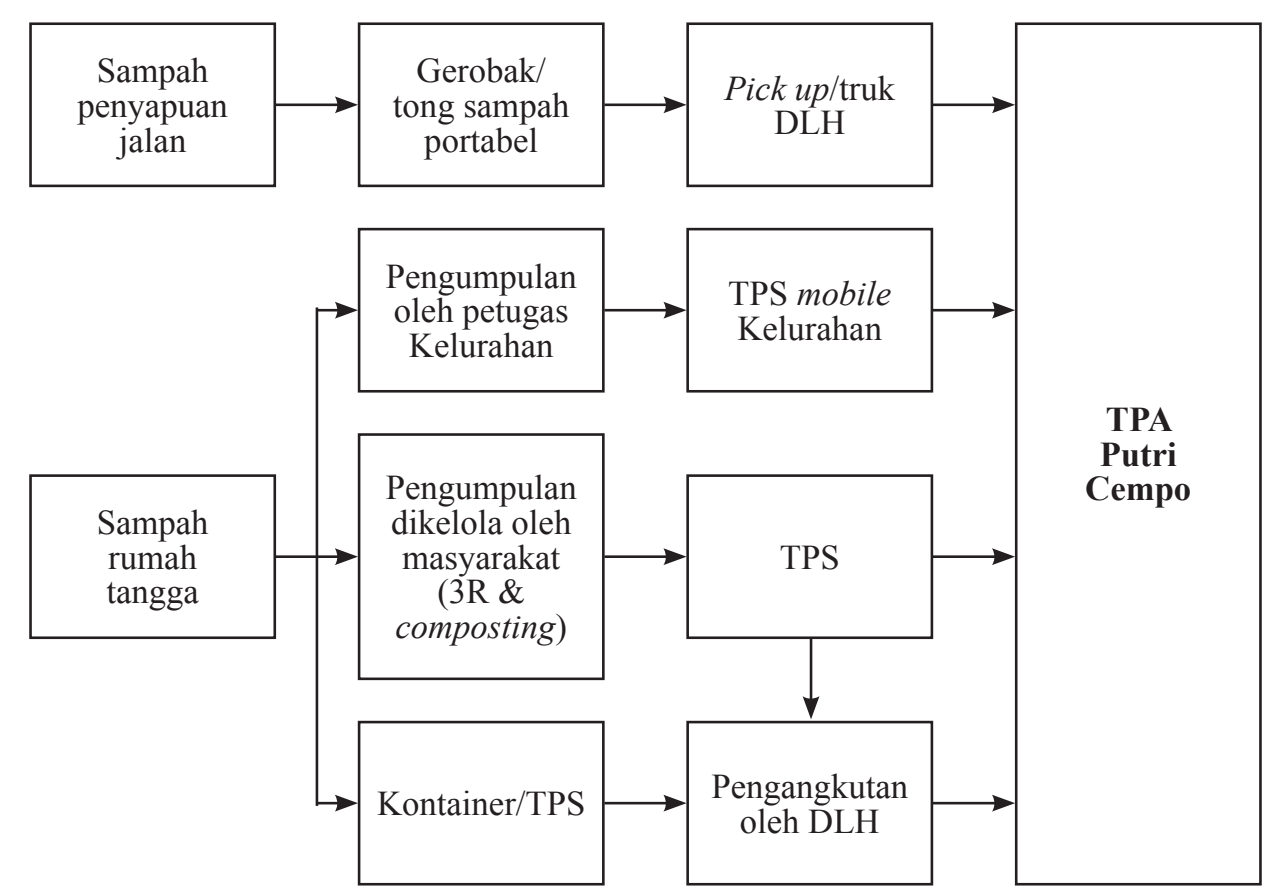

Bagan 2. Alur Pengelolaan Sampah di Kota Surakarta

Sumber: Dinas Lingkungan Hidup Kota Surakarta, 2018: 30

Sementara itu, jika dilihat dari komposisi, sampah di Kota Surakarta disajikan pada Grafik 1 sebagai berikut:

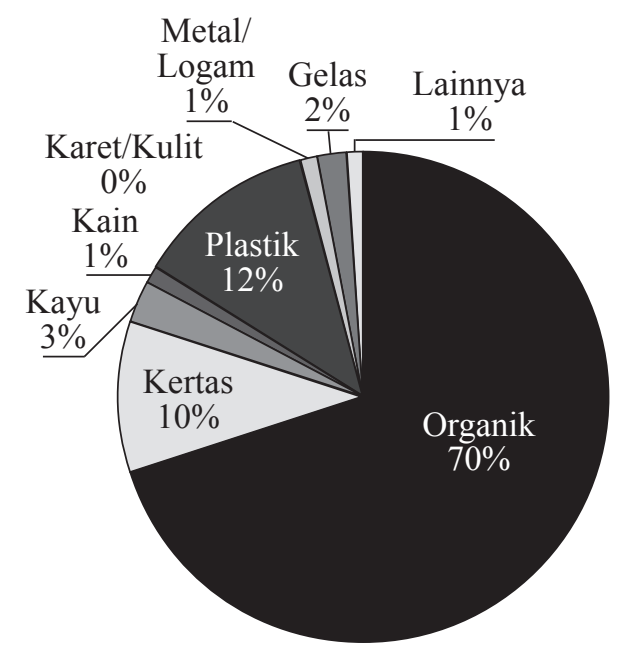

Grafik 1. Komposisi Sampah di Kota Surakarta Sumber: Triyono \& Patola, 2015
Grafik 1 menjelaskan mengenai perbandingan komposisi sampah di Kota Surakarta pada tahun 2013. Komposisi sampah organik menempati persentase yang lebih tinggi daripada komposisi sampah yang lain yaitu sebesar 70,34\%. Persentase komposisi sampah yang terkecil berasal dari karet/kulit yaitu sebesar $0,43 \%$.

Salah satu inovasi yang dilakukan oleh Pemkot Surakarta adalah dengan membuat mobil pick up pengangkut sampah dengan model dump truck agar memudahkan proses membongkar sampah pada waktu di TPA (Gambar 1). Dengan beroperasinya mobil pick up ini maka setiap pengelola TPS tidak perlu lagi menginapkan sampahnya yang umumnya membuat bau tidak sedap di dalam kota. Semua sampah yang terkumpul di TPS akan secepatnya diangkut dan dikirim ke TPA. 


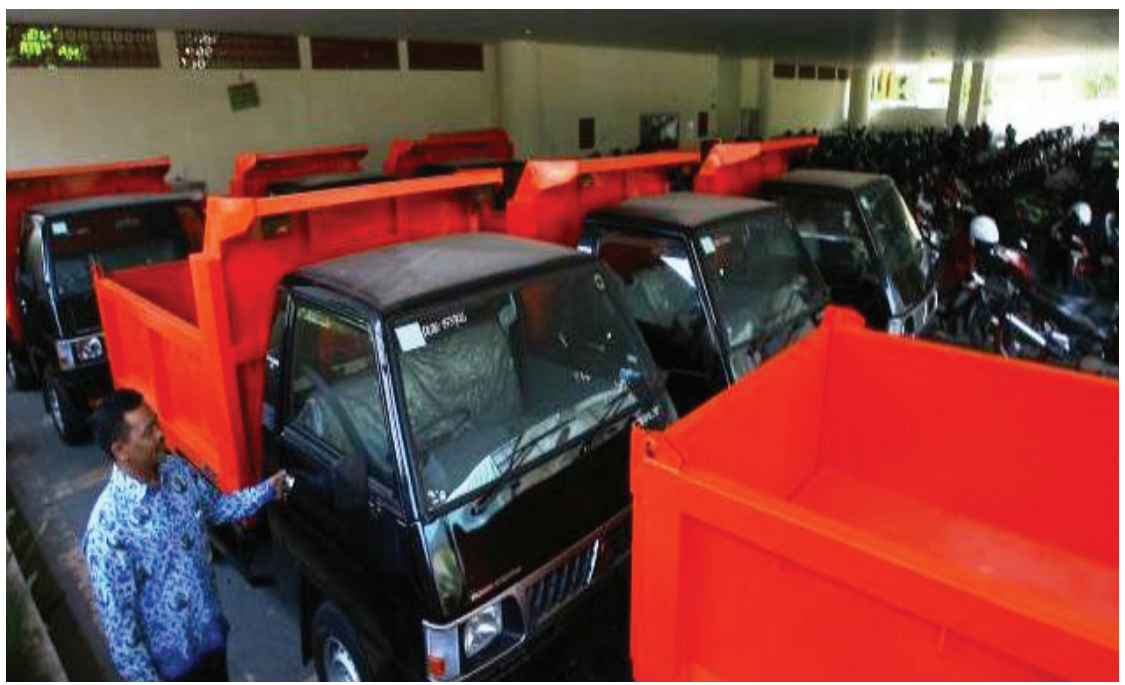

Gambar 1. Armada Pengangkutan Sampah Kota Surakarta

Sumber: Dokumentasi Penelitian, 20 Oktober 2018

Dari sisi pengelolaan sampah, inovasi tersebut sebenarnya inovasi yang sifatnya masih parsial karena tujuannya hanya mempercepat pola pengangkutan sampah dari TPS menuju ke TPA. Memang benar, tumpukan sampah di TPS tidak ada yang sampai menginap lebih dari satu malam serta tidak menimbulkan bau, namun substansinya sampah tersebut hanya beralih dari TPS ke TPA saja. Ketika sampai di TPA, sampah tersebut tidak diolah namun hanya ditumpuk dan ditumpuk secara terus menerus (open dumping). Cepat atau lambat, pola ini akan membuat TPA Putri Cempo melebihi kapasitas atau daya tampungnya, dan Pemkot Surakarta harus mencarikan lokasi baru untuk TPA pengganti. Padahal pada saat ini, mencari lokasi lahan baru hampir mustahil ditemukan, kecuali di luar wilayah Kota Surakarta.

TPA yang ada di Kota Surakarta yaitu TPA Putri Cempo, yang memiliki luas 17 ha, sudah mulai beroperasi mulai tahun 1987 dan dapat menampung sampah sebesar 100.000 ton. Sampah yang dibuang ke TPA tersebut tiap tahunnya mengalami peningkatan. Peningkatan volume sampah disebabkan oleh pertambahan jumlah penduduk yang berimbas pada besarnya sampah yang dibuang ke TPA. Peningkatan sampah tersebut akan berimbas bagi berkurangnya umur layan TPA (Lesmana, 2016).
Meningkatnya volume sampah di Surakarta telah menimbulkan masalah yang kompleks dalam pengelolaan sampah. Untuk itu dibutuhkan strategi yang efektif untuk mereduksi volume sampah sejak dari sumbernya, terutama sampah domestik, di mana setiap rumah tangga berperan penting di dalamnya.

Salah satu strategi efektif untuk mereduksi volume sampah dari sumbernya adalah meningkatkan peran serta masyarakat dalam mengurangi munculnya sampah antara lain melalui implementasi bank sampah secara masif. Sampah itu bagi orang yang tidak paham maka hanya akan menjadi barang buangan. Padahal di sana ada nilai kemanfaatannya baik yang menghasilkan uang, pupuk, dan nilai sosial serta pendidikan bagi masyarakat.

Melalui bank sampah ini diharapkan warga dapat menyadari pentingnya mengelola sampah sekaligus mendaur-ulang sampah. Sejak tahun 2015, Pemkot Surakarta sebenarnya gencar melakukan sosialisasi di masing-masing kelurahan tentang bank sampah. Materi sosialisasi termasuk bagaimana pengelolaan sampah dengan baik dan benar dilakukan, serta pemanfaatan sampah organik dan anorganik.

Berikut ini adalah data bank sampah yang terdaftar di Dinas Lingkungan Hidup Kota Surakarta: 
Tabel 1. Daftar Bank Sampah di Kota Surakarta

\begin{tabular}{lllc}
\hline \multicolumn{1}{c}{ Nama Bank Sampah } & \multicolumn{1}{c}{ Kelurahan } & Kecamatan & $\begin{array}{c}\text { Tahun } \\
\text { Berdiri }\end{array}$ \\
\hline Sejahtera & Joyotakan & Serengan & 2016 \\
Ngudi Resik & Jayengan & Serengan & 2017 \\
Sumber Rejeki & Serengan & Serengan & 2016 \\
Sumber Rejeki & Kemlayan & Serengan & 2016 \\
Kangen Makmur & Kratonan & Serengan & 2016 \\
Peni Asri & Tipes & Serengan & 2016 \\
Rejeki Lancar & Danakusuman & Serengan & 2017 \\
Guyub Rukun & Banyuanyar & Banjarsari & 2017 \\
Ngudi Rejeki & Keprabon & Banjarsari & 2017 \\
Berkat Melimpah & Kadipiro & Banjarsari & 2018 \\
Madyo Taman & Punggawan & Banjarsari & 2017 \\
Uwuh Aji & Gilingan & Banjarsari & 2015 \\
Ngudi Rejeki & Nusukan & Banjarsari & 2017 \\
Ngudi Rejeki & Kedunglumbu & Pasar Kliwon & 2016 \\
Kampungbaru & Kampungbaru & Pasar Kliwon & 2016 \\
Komunitas Sriwaru & Sondakan & Laweyan & 2017 \\
Gardu Resik & Jajar & Laweyan & 2017 \\
Berkah & Purwosari & Laweyan & 2016 \\
Sampah Barokah & Pajang & Laweyan & 2017 \\
Karunia & Mojosongo & Jebres & 2016 \\
Berkah & Jagalan & Jebres & 2016 \\
Wanita Kreatif Gulon Asri & Jebres & Jebres & 2018 \\
Purwo & Purwodiningratan & Jebres & 2018 \\
\hline
\end{tabular}

Sumber: Dinas Kebersihan Kota Surakarta, 2018

Sementara itu, menurut wawancara tanggal 20 Oktober 2018 dengan Siti Aminah yang merupakan pendiri sekaligus pengelola sebuah bank sampah di Kelurahan Kadipiro, Surakarta, sampah yang ada di masyarakat jenisnya ada tiga, yakni yang layak kompos, layak jual, dan layak buang (Aminah, 2018). Sayangnya sampai saat ini keberadaan bank sampah belum dapat mengurangi secara signifikan timbulan sampah yang ada di masyarakat. Harusnya keberadaan bank sampah di Kota Surakarta ini dapat mengurangi kumpulan sampah yang terjadi di level rumah tangga dan kelurahan. Melalui pengolahan sampah yang baik di kedua level tersebut diharapkan volume sampah pada level Kota Surakarta dapat teratasi sehingga beban pembuangan sampah di TPA Putri Cempo dapat teratasi.

Studi yang dilakukan oleh Triyono dan Patola (2015) telah membuktikan bahwa struktur geologi TPA Putri Cempo merupakan batuan alluvial kelabu dan regosol kelabu searah yang ditambah dengan kemiringan lahan sehingga memudahkan rembesan lindi ke arah timur dan utara kawasan permukiman. Akibatnya, TPA Putri Cempo terbukti telah mencemari air di lingkungan sekitarnya sampai radius $150 \mathrm{~m}$. Menurut Permendagri Nomor 33 Tahun 2010 tentang Pedoman Pengelolaan Sampah, sistem open dumping sudah tidak diperbolehkan. Namun demikian, pengelolaan sampah di TPA Putri Cempo pada saat ini masih bersifat open dumping. Oleh karena, itu perlu upaya untuk mengubah sistem open dumping menuju ke sistem controlled landfill yang lebih ramah lingkungan.

Upaya lain yang sedang dilakukan Pemkot Surakarta adalah dengan menggandeng pihak swasta untuk membangun Pembangkit Listrik Tenaga Sampah (PLTSa). Rencana pembangunan PLTSa merupakan rencana lama sejak tahun 2011 dan sampai saat ini belum terwujud karena masih mengalami kendala pendanaan.

Hampir mirip yang terjadi di wilayah sekitar Kota Cirebon, TPA di Kota Surakarta, Kabupaten Sukoharjo, dan Kabupaten Karanganyar juga mencapai batas umur dan masih dioperasikan secara open dumping. Perencanaan pembangunan 
TPA regional dengan menerapkan sistem sanitary landfill dan disertai instalasi pengolahan lindi merupakan salah satu cara untuk menggantikan peran TPA sebelumnya. Dampak adanya pembangunan instalasi pengolahan lindi, air lindi dapat diolah terlebih dahulu sehingga tidak mencemari lingkungan sekitar.

Selain itu, Pemkot Surakarta juga terus mendorong lahirnya kesadaran masyarakat melalui pendirian bank-bank sampah di level masyarakat. Upaya ini walau belum terlihat menggembirakan namun harus terus didorong agar permasalahan pengelolaan sampah di Kota Surakarta tidak hanya dilakukan oleh sektor pemerintah saja. Cepat atau lambat, masyarakat sebagai penghasil sampah itu sendiri harus diajak untuk ikut bertanggung jawab dalam mengurangi (reduce), menggunakan kembali (reuse), dan mendaur ulang (recycle) sampah yang mereka buat. Hanya dengan cara ini maka potensi timbulan sampah di TPA Putri Cempo dapat dikurangi.

\section{Penutup}

Pengelolaan sampah di Kota Cirebon dan Kota Surakarta masih menerapkan pola 3P (pengumpulan, pengangkutan, dan pembuangan). Artinya, pengelolaan sampah di kedua kota tersebut dilakukan dengan dikumpulkan sebanyak-banyaknya, kemudian diangkut secepat-cepatnya, dan setelah itu dibuang sejauh-jauhnya. Pola tersebut menyebabkan sampah di kedua kota akan timbul lebih cepat ketimbang solusi pengelolaan sampah. Akibatnya, TPA di kedua kota itu sudah tidak mampu lagi memberikan daya dukungnya. Paradigma lama pengelolaan sampah yang hanya berupa kumpul-angkutbuang tanpa melalui pengolahan terlebih dahulu akan menyebabkan sampah bertumpuk di TPA. Padahal semakin lama, lahan di perkotaan yang akan digunakan untuk TPA semakin terbatas, langka, dan tentu akan sangat mahal. Kendala lain yang dihadapi kedua kota tersebut adalah susahnya mencari lahan pengganti TPA sehingga sangat bergantung pada keberadaan lahan di wilayah lain. Di samping itu, dari sisi postur APBD, terlihat bahwa anggaran Dinas Kebersihan dan Pertamanan masih sekitar 1\% dari total APBD sehingga sangat sulit untuk mengimplementasikan perencanaan pengelolaan sampah yang baik.

TPA Putri Cempo di Kota Surakarta dan TPA Kopi Luhur di Kota Cirebon sama-sama masih menerapkan pola open dumping yaitu sistem pengolahan sampah paling sederhana di mana sampah dibuang begitu saja ke sebuah TPA tanpa perlakuan lebih lanjut. Sistem pembuangan open dumping pada akhirnya akan menimbulkan persoalan mulai dari kontaminasi air tanah oleh air lindi, bau, ceceran sampah hingga asap. Daya tampung TPA di kedua kota tersebut yang sudah mendekati batas maksimal perlu menjadi perhatian. Selanjutnya perlu ada perencanaan yang matang terkait dengan upaya revitalisasi TPA, mempercepat realisasi pembangunan Tempat Pengolahan dan Pemrosesan Akhir Sampah (TPPAS) Regional, serta sosialisasi dan edukasi terus-menerus agar masyarakat mulai sadar pentingnya keterlibatan masyarakat dalam menjalankan program pengelolaan sampah berbasis komunitas.

Lahirnya UU Pengelolaan Sampah sebenarnya merupakan tonggak baru dalam mengubah paradigma pengelolaan sampah di Indonesia. UU ini jelas menitikberatkan pengelolaan pada pengurangan sampah ketimbang penanganan sampah. Pengurangan sampah yang dimaksud terdiri dari pembatasan timbulan sampah, pendauran ulang sampah, dan/atau pemanfaatan kembali sampah. Secara umum terdapat dua macam pengelolaan sampah yaitu pengurangan dan penanganan. Dalam pengurangan sampah, masyarakat memegang peranan penting, karena sumber awal munculnya sampah berawal dari aktivitas sehari-hari masyarakat yang memang tidak bisa lepas dari sampah. Keberhasilan dari pengurangan sampah ini tergantung pada usaha masyarakat dalam mengurangi produksi sampah di Kota Cirebon dan Kota Surakarta.

\section{Daftar Pustaka}

Aminah, S. (2018). Pengelolaan Sampah Berbasis Masyarakat/Pewawancara: Rohani Budi Prihatin, Pusat Penelitian Badan Keahlian DPR RI, Surakarta. 
Anschütz, J. 1996. Community-based Solid Waste Management and Water Supply Projects: Problems and Solutions Compared - a survey of the literature. Urban Waste Expertise Programme (UWEP) Nieuwehaven. UWEP Working Document 2.

Badan Pusat Statistik Kota Cirebon. (2018). Jumlah Penduduk Per Kelurahan di Kota Cirebon Tahun 2016. Retrieved from https://cirebonkota.bps. go.id/dynamictable/2019/09/06/67/ jumlahpenduduk-per-kelurahan-di-kota-cirebontahun-2016---2018.html, on April 28, 2020.

Badan Pusat Statistik Kota Cirebon. (2016). Profil Kota Cirebon. Cirebon: Badan Pusat Statistik Kota Cirebon. Retrieved from http://bappeda. cirebonkota.go.id/wp-content/upload, on April 28, 2020.

Badan Pusat Statistik Kota Surakarta. (2018). Jumlah Penduduk Menurut Kelompok Umur dan Jenis Kelamin di Kota Surakarta Tahun 2018. Retrieved from https://surakartakota.bps.go.id/ statictable/2019/11/25/87/jumlah-pendudukmenurut-kelompok-umur-dan-jenis-kelamin-dikota-surakarta-tahun-2018.html, on April 28, 2020

Badan Perencanaan Pembangunan Nasional (Bappenas). (2010). Indonesia Climate Change Sectoral Roadmap. Jakarta: Bappenas.

Damanhuri, E. (2007, November 23). Tren Global dalam Pengelolaan Sampah Kota. Paper in Simposium Pengembangan Surabaya Metropolitan Area di Masa Depan- Sub Topik Manajemen Sampah Kota. Jurusan Teknik Sipil ITS, Surabaya, November 23, 2007.

Dinas Lingkungan Hidup Kota Surakarta. (2018). Integrasi Data Informasi Lingkungan Hidup Berbasis Website di Dinas Lingkungan Hidup Kota Surakarta. Retrieved from https://dlh. surakarta.go.id/new/buku-integrasi.pdf, on April 28, 2019.

Dinas Kebersihan Kota Surakarta. (2018). Daftar Bank Sampah di Kota Surakarta. Surakarta: Dinas Kebersihan Kota Surakarta.

Emillia, H. H. (2019). Aplikasi Fungsi Manajemen Dalam Pengelolaan Sampah Terpadu. Jurnal Kreatif, 7(1) 2019, 1-17.

Isni, N. N., Sungkowo, A., \& Widiarti, I. W. (2019). Upaya Teknis Rehabilitasi TPA Sampah Kopi Luhur dengan Sistem Lahan Urug Terkendali. Jurnal Ilmiah Lingkungan Kebumian, 2(1), 2433.
Meidiana, C. \& Gamse, T. (2011). The New Waste Law: Challenging Opportunity for Future Landfill Operation in Indonesia. Waste Management \& Research, 29(1), 9-20. doi: $10.1177 / 0734242 X 10384013$.

Mukti, A. H. (2018, January 11). Bank Sampah di Solo Belum Maksimal, Produksi Sampah Masih 270 Ton Per Hari. Jateng Tribunnews. Retrieved from http://jateng.tribunnews.com/2018/01/11/ bank-sampah-di-solo-belum-maksimalproduksi-sampah-masih-270-ton-per-hari, on November 8, 2018.

Munawar, E. \& Fellner, J. (2013). Landfilling in Tropical Climates: Measures for Better Design and Operation. Proceeding Conference: ISWA World Congress 2013, Vienna, Austria, October 7-11, (pp. 1-14).

Kepala Seksi Pengelolaan Sampah Dinas Lingkungan Hidup Kota Surakarta (2018). Pengelolaan Sampah di Kota Cirebon dan Surakartal Pewawancara: Rohani Budi Prihatin, Pusat Penelitian Badan Keahlian DPR RI, Surakarta.

Kepala Dinas Lingkungan Hidup Kota Cirebon (2018). Pengelolaan Sampah di Kota Cirebon dan Surakarta/Pewawancara: Rohani Budi Prihatin, Pusat Penelitian Badan Keahlian DPR RI, Cirebon.

Kuncoro, S. (2009). Pengelolaan Sampah Terpadu dengan Sistem Node, Sub Point, dan Center Point. Yogyakarta: Kanisius.

Lesmana, R. Y. (2016). Layanan Persampahan di Kota Surakarta dengan Pemetaan Berbasis Sistem Informasi Geografis. Jurnal Media Ilmiah Teknik Lingkungan, 1(1), Februari 2016.

Letcher, T. M. \& Valerro, D. A. (2019). Waste: A Handbook for Management (Second Edition). London: Elsevier and Academic Press.

Paramita, M. (2016). Strategi Membangun Kota. Yogyakarta: Housing Resource Center Carita.

Pemerintah Kota Cirebon. (2017). Dokumen Informasi Kinerja Pengelolaan Lingkungan Hidup Daerah Kota Cirebon Tahun 2017. Retrieved from http:// perpustakaan.menlhk.go.id/pustaka/images/ docs/IKPLHD\%20CIREBON\%202017.EDIT. pdf, on June 14, 2020.

Pepep. (2018). Pengelolaan Sampah Berbasis Masyarakat/Pewawancara: Rohani Budi Prihatin, Pusat Penelitian Badan Keahlian DPR RI, Cirebon. 
Purwanta, W. (2009). Perhitungan Emisi Gas Rumah Kaca (GRK) dari Sektor Sampah Perkotaan di Indonesia. Jurnal Teknik Lingkungan, 10(1), 1-8.

Qodriyatun, S. N. (2018). Sampah Plastik: Dampaknya Terhadap Pariwisata dan Solusi. Info Singkat, 10(23), 13-18.

Radar Cirebon. (2018, August 26). Kota Cirebon Bukan Tempat Sampah? Radar Cirebon. Retrieved from https://www.radarcirebon. com/2018/08/26/kota-cirebon-bukan-tempatsampah/, on April 28, 2020.

Redaksi Aktual. (2016, February 2016). Cemari Pemukiman Warga, Pemkot Cirebon Didesak Tutup TPA Kopiluhur. Aktual. Retrieved from https://aktual.com/cemari-pemukiman-wargapemkot-cirebon-didesak-tutup-tpa-kopiluhur, on April 28, 2020.

Soleman, S., Jaenudin, \& Erawan, S. P. (2017). Hubungan Program Bank Sampah Rumah Zakat dengan Peran Serta Masyarakat dalam Membuang Sampah di Kelurahan Kesepuhan Kota Cirebon. Jurnal Kesehatan Maharika, 4(1).

Tim Riset dan Analis Katadata. (2019, December 10). Kelola Sampah Mulai dari Rumah. Retrieved from https://katadata.co.id/analisisdata/2019/11/26/ kelola-sampah-mulai-dari-rumah, on April 23, 2020.

Triyono, K. \& Patola, E. (2015). Studi Tempat Pembuangan Akhir (TPA) Sampah: Studi Kasus di TPA Putri Cempo Kota Surakarta. Jurnal Joglo, 27(2), 264-271.

Wibowo, A. (2009, April 17). Kondisi Persampahan Kota di Indonesia. Retrieved from https:// narasibumi.blog.uns.ac.id/2009/04/17/kondisipersampahan-kota-di-indonesia/, on April 28, 2020. 